Anckaert, L., Language, Ethics, and the Other between Athens and Jerusalem: A

Comparative Study of Plato and Rosenzweig , Philosophy East and West, 45:4

(1995:Oct.) p.545

\section{LANGUAGE, ETHICS, AND THE OTHER BETWEEN \\ ATHENS AND JERUSALEM: A COMPARATIVE STUDY OF PLATO AND ROSENZWEIG}

L. Anckaert

Katholieke Universiteit Leuven
The initial hypothesis of this comparative study of a moment in Greek and Jewish philosophy states that the way of speaking determines the way in which reality can be narrated, which reality can be narrated, and which type of relationality becomes possible. The perception of reality forms the basis of the possible types of relationality and is constitutive for its (ethical) patterns. The cultural world is formed by the way in which it can be narrated by humanity.

This hypothesis is elaborated by investigating two types of reality perception for their respective (implicit) understandings of literary genres as modes of narrating reality and, more formally, for the relationality in which these texts function. The first aspect is inspired by the studies of Auerbach and Wertheimer, ${ }^{1}$ the second by literary criticism and those new strategies of reading that consider the text in its relation to the author and the reader ${ }^{2}$ and which examine how the meaning of the text is produced. ${ }^{3}$

Plato and Rosenzweig as Dialogical Thinkers

Dialogical thinking is marked by a long, rich, and changing history. The dialogues of Plato are generally considered its origin while the Jewish dialogical thinking of the beginning of this century can be interpreted as its Nachgeschichte. ${ }^{4}$ But the differences between these two stages of dialogical thinking are noteworthy. Plato uses the literary genre of the dialogue in which the partners search together for true knowledge, while someone like Rosenzweig, who wrote undoubtedly one of the most important texts of dialogical thinking, abandons the form of dialogue for a narrative (epic) philosophy closer to the later Schelling. Nonetheless, Rosenzweig pays more attention to the dialogical character of reality than does Plato, whose dialogues are, from a Jewish-philosophical point of view, often understood as monologues in which 'the same' is liberated from forgetfulness by a maieutic discourse. ${ }^{5}$ The text of Plato can be considered an immanent dialogue, while Rosenzweig's discursive manner of speaking presupposes instead a dialogue with the reader. This formal paradox has much to do with the place and the meaning of the 'third'. The third can appear as an instance of exteriority or alterity and take the form of an irreducible partner in the dialogue. A deeper study of Plato shows that this third is excluded or repressed. This repression is in a certain sense constitutive for the texts of Plato. It manifests itself in the study of the different literary genres or genres de discours that are allowed in the discourse of Plato. On the other hand, Rosenzweig
Philosophy East \& West Volume 45, Number 4 October 1995

545-567

(C) 1995 by University of Hawai'i Press 
reflects on the place and the meaning of this third party. This third appears as the second grammatical pronoun, the You, in a metaphorical discourse of the trial. At the same time, his work is a challenge to the reader, who also forms an aspect of this third party. In other words, the immanent character of Plato's dialogue sets aside real intersubjectivity while the more objective character of Rosenzweig's text permits these relations.

Plato's Logomachy of Language

In literary criticism one distinguishes three literary genres: lyrics, epics, and drama (cf. Goethe). According to the Redeverteilungskriterium, the question of who speaks, the genres can be connected with the three grammatical pronouns. One of the possible structures consists in binding lyrics with the monological enactment of a situation (first person), epics with the monological narration of an action (third person), and drama/rhetoric with the dialogical enactment of an action (second person). This division can be connected with the fundamental times of present, past, and future.

The Battle of Rhetoric. In the famous opening book of the Republic, Plato refuses to situate his discourse in the field of rhetoric. ${ }^{6}$ Plato gave much attention to the opening and the setting of the Republic. Dionysius of Hallicarnassus relates that in the heritage of Plato a tablet was found on which the first period of the dialogue was written down in different forms. ${ }^{7}$ It is also agreed that the first book circulated for a long time as a separate dialogue and that Plato himself integrated it as the opening of the Republic. These remarks show the difficulties connected with the act of writing on Justice. Seemingly, it is necessary to take certain decisions on language and the structures of speech before being able to speak of a determined aspect of reality. Language has to go through a crisis before it can be spoken.

The first book of the Republic is a battle with rhetoric. Together with drama, rhetoric is the expressed genre of the second grammatical person. Rhetoric tries to seduce the other with beautiful words in a wellformulated discourse. This discourse is connected with power. The spoken word is a dynastēs, which can present the ugly as beautiful, the bad as good, and the detestable as honorable. ${ }^{8}$ Rhetoric is the word of the democratic city with its agora and its trial. The opening of the Republic narrates on Socrates, who is outside Athens. In returning to the city, a boy catches hold of his himation from behind and forces him to go back to Polemarchus (327b). After this physical encounter, Socrates again wants to go back to the city, but different arguments retain him: physical power, the seduction of a torchlight race on horseback, a night festival, and young boys with whom Socrates can converse (327c-328a). This rhetorical scene of seduction opens the discussion on justice: the ethical reflection starts with rhetoric and language. 
Outside the city, a conversation about justice takes place. Three people open the conversation. Old Cephalus, metaphor for the epithumia ${ }^{9}$ considers justice to be truth-telling and recompense for what one has received. His son Polemarchus sees justice as rendering each his due. He understands justice to begin from the striving part of the soul. The young rhetorician Trasymachus rushes in like a wild beast to tear his discussion partners to pieces. In a forceful act, rhetoric tries to turn that serene conversation into a direct confrontation in which justice is determined by the interests of the strong. This form of justice is situated in a political context, regulated by the idea of the formulation of society through the nomos. ${ }^{10}$ The sphere of the nomos, or conventions, is familiar with the sphere of the doxa, the shadow of true reality. Rhetoric therefore belongs among the ambivalent forms of art.

The action of Trasymachus introduces a rupture in the dialogue, a crisis in language. Two texts are important here. Section 336d narrates how Socrates defuses rhetorical power by turning first to look at Trasymachus. This first look makes it possible for Socrates to give an adequate answer without loosing his language. The visual positions of the partners in the dialogue grounds the possibility of speaking in rhetoric. The rhetorician always speaks from a well-circumscribed location. His place is related to and made possible by the others. Socrates is able to develop his discourse from the fact that his own language (irony) comes to a crisis, and from the fact that he takes the first initiative in this crisis: "I glanced at him first, so that I became capable of answering him." The possibility of aphasia, the fall of language, is interrupted by the initiative of the first grammatical pronoun. The first person resists the disturbing power of the meeting with the other, who is pictured as an animal (336b and 341c). Here, the look is of central importance.

The second text is situated between the two discussions of Socrates and Trasymachus $(348 \mathrm{a}-\mathrm{b})$. Earlier there were already some allusions to the metaphor of trial. Penalty, ransom (337d), and witnesses (340a) were all mentioned. These rhetorical metaphors are reflected in 348a-b. A fundamental choice is made concerning the way in which conversation can take place. A first rhetorical possibility is the agonistics in which a discussion between equals is decided by putting aside the different arguments (eris). A third person makes the final decision. The eris is parallel to warfare, but with the violence interior. A judge (kritēs) can decide which of the two parties is right. But Socrates proposes to be at the same time judge and advocate, and this in a kind of immanent dialogue of an ideal community, an enlargement of the first grammatical pronoun, in which the investigation can be perpetuated. The critical judgement of a third instance is hereby excluded and an immanent pattern of communication becomes possible. This pattern seems to be the presupposition for a discussion of justice. 
The Organization of the Genres. The first book of the Republic describes a crisis of language that leads to an unambiguous choice. The third critical instance of the judge is excluded. The result is an immanent community in which communication is directed by the ideas. The triadic structure of the two opponents who debate before a jury is replaced by a binary structure in which every judge becomes a participant in the dialogue. This exclusion was aimed at rhetoric.

A reading of the succeeding books shows that the classic literary genres are excluded in the same way. ${ }^{11}$ Plato structures the forms of art according to the still dominant epics-lyrics-drama triad: "And now I think I can make plain to you what I was unable to before, that there is one kind of poetry and tale-telling which works wholly through imitation, as you remarked, tragedy and comedy; and another which employs the recital of the poet himself, best exemplified, I presume, in dithyramb; and there is again that which employs both, in epic poetry and in many other places, if you apprehend me" (394b-c). Drama (tragedy and comedy), epics, and lyrics (dithyrambs but also more implicit didactics) show a descending grade of mimēsis. At two points these forms of art are evaluated and/or excluded.

In the first text, the literary genres are discussed in the frame of the education of the guardians of the republic (376c-403c). The good guardian has to fulfill a double condition: he has to be gentle to the friendly and harsh to the hostile. The meaning of this distinction, which is a form of philosophy (376b), can be fostered by gymnastics and music, on the condition that they are attuned to each other harmoniously. Concerning music, a distinction is made between its true and false forms (376e). Epics and drama seem especially mendacious to Plato and are therefore rejected for education. Their muthos puts a stamp or tupos (377b) on the student. Plato formulates a double criticism and hands down a double criterion for judgment on their place in the republic. The first material criticism is theological. As tupoi, the tales have to correspond to a higher tupos that is a nomos. The first norm or canon of narrative speaking consists in asserting that God is not the cause of all things, but only of the good (380c). The second canon is the tupos that the gods neither are wizards in shape-shifting nor mislead men by falsehoods in words or deeds (383a). The second criticism has to do with moral life. Mendacious tales can pervert the heart by, for example, wrong representations of the hereafter. The virtuousness of the guardians consists in the fact that under all conditions they preserve the true sense of what is to be feared, that is, that the things to be feared are those that the legislator conveyed in his education and that they are as he conveyed them. Such education occurs according to the law (429c). Those tales that do not fulfill these conditions are to be banned from the republic according to the law. 
These two criticisms open up the following consideration. Plato excludes two important literary genres: the epic and tragedy. The material reason is that these narrative wholes cannot function in the ideal republic and can even be harmful. They are therefore to be censored and exposed to judgment on their ontotypological value. ${ }^{12}$ This judgment can be passed by the philosophical class. All autonomy of arts is ruled out. Moreover, this interpretation leads to the problematic of the necessary lie. Plato links the forms of art with the false or mendacious and the false with ignorance. But as a pharmakon (382c), the lie is necessary to keep out certain dangers. A close reading of the Republic shows that certain necessary lies or forms of art are to be introduced as legitimate fundamental options. In the first place, there is the myth of autochthony $(414 d-e)$ and the myth of the metals $(415 a-d)$. These are epic tales that instate the fundamental distinction between mine and yours. Besides this, there is the lie that regulates genetic selection and organizes the patterns of relation or the structure of desire $(459 c-e)$. These lies are unavoidable. As a crisis of the truth they direct the guardians to the common good.

Two genres are eliminated on the basis of material reasons. Epics or tales about the origins are excluded as being subversive for the established order. Tragedy, as the direct confrontation of the dramatis personae, is also moved from the scene of platonic dialogue. Nevertheless they can be replaced by ideological texts. But there is also a more severe reason to exclude them. Tragedy and the epic are modes of an extremely dangerous form of mimēsis. This criticism is aimed at the way of speaking (lexis). Tragedy is marked by the fact that the actor and author identify themselves with the role of the character (393b). Speaking in direct discourse makes it possible for the actor to imitate his character. Owing to this it becomes difficult to discern who in fact speaks. The veracity of the speaker is discredited because the content of the message is uncoupled from the speaker. In this respect, tragedy is the most mimetic art. The mimetic dimension of tragedy renders it unfit as a medium of the truth. In the currency of the present there is a kind of dionysiac transsubstantiation in which a person takes over the role of the other. ${ }^{13}$ Indirect discourse creates, on the contrary, a distance between the narrator and the characters. ${ }^{14}$ In other words, mimetic identification becomes a threat because one becomes equal to the other. The original narrator is absent from the text that is recited and his place is taken over by another. Might not this mimetic identification be the background for Plato's logophobia; that is, might he not be responding to the possible perversion of a text in its parody by another?

There remains only the pure style of dithyrambic poetry. As directly written down, the dithyramb displays the traces of the authentic writer or speaker. But the music is also subject to certain conditions. The most 
important component of music is the word, the logos (400a). This logos has to be directed to the already mentioned tupoi. Only the panegyric to the gods and the heroes can have a place in the republic. Concerning the melody, lamentation is to be avoided. There remain only two tunes: the tune of imposed obligation and the tune of free acceptance (399c). Music remains important because of the fact that "rhythm and harmony find their way to the inmost soul and take strongest hold upon it, bringing with them an imparting grace" (401d). The ultimate condition for the acceptance of music is knowledge of the eide (402c-d). Music is the only form of art that leads to the realm of beauty (403c). It makes the soul gentle to its own people. In this sense, it is to be combined with gymnastics.

Because of this decision, dialogue appears as the preeminent philosophical genre. The partners in the dialogue are one another's witnesses instead of judges. A witness as an external or third instance is of no worth for the truth (Gorgias 471e-472b, 474a-b, 475d-476a, and, the Republic, 454a-b). The mere fact that two people agree on a sentence (homologia) is a sign of the truth. Outside those people who themselves speak of the referent (the truth), no witnesses are admitted. This is in extreme contrast with rhetoric as the art of discussion in which the subject cannot be simply contemplated but is ensnared in a dispute and an eris. According to Plato, true rhetoric or dialogue is the art that leads the soul by means of the logos and that comes to the truth by means of conversation. Submission to the commonly desired truth excludes every third instance. In the Republic a choice is made for the anhomologia instead of the diakrinein (348a-b).

The Exclusion of Art through the Ideal of Philosophy. After the decisive structuration of language, Socrates, in the course of the ensuing dialogue, develops justice as consisting in the fact that every class of people does its own business according to natural inclination. The principle of justice opens up the possibility that intelligence, courage, and soberness have a place in the republic, and it ensures their existence (433a). Justice in an individual person consists in ordering the three parts of the soul such that they restrain one another. Plato pursues harmony between society and individual life. His starting point is the principle of noncontradiction: "It is obvious that the same thing will never do or suffer opposites in the same respect and at the same time" (436b). This principle functions as a hypothesis (437a) structuring the whole dialogue.

This interpretation of justice is attained by an art of conversation seeking the fundamental nature or the essence. Insight into justice and personal harmony are conditions stipulated for the candidate to rule society. Only the philosopher fulfills this double condition. In the main part of the Republic, the education of the philosopher-guardian is 
explored further. The comparison with the sun, the image of the line, the allegory of the cave and its explanation deepen the insight of justice and the community in which the philosopher can reign.

The possibly hierarchical interpretation of society, in which concrete political action is deduced from a tupos of justice-and which is in this sense a form of poiēsis or ontotypology - is opened up and even made possible by the idea of the Good. The Good is an exteriority that transcends being and makes knowledge possible. The idea of the Good gives to the object of knowledge its character of truth and to the knowing subject its power and capacity for knowledge. The Good makes it possible to climb by the force of dialogue to the highest principles. But above all, this Good asks for a conversion (518d: periagogē) from the world of shadows and doxa to the ideas. The candidate-philosopher or politician therefore must endure a decisive crisis in his education, which is thus described as the art of conversion. The first crisis in determining justice consisted in criticism of the mimetic forms of language situated in the world of theatrical opinion. The second crisis consists in leaving the visible world in order to transcend it by contemplating the ideas. This moment of crisis exhibits the true meaning of philosophy. Philosophy is a case of conversion, of crisis and decisive choice. The philosopher has to die from the world of opinions. Dying and being dead is the main purpose of philosophy (Phaedo 64a). Dying means leaving the supposed truths that are only the shadow of the true reality. Thus understood, philosophy is an ars moriendi as well as a conversion. ${ }^{15}$ A certain perception of reality is left behind that implies the death of a worldview in favor of another perception. This means that philosophy consists of an option that breaks with common opinion insofar as it is present in dominating tales. Philosophy is oriented by the dazzling power of the Good that makes these tales possible. The condemnation of art is a consequence of a life-option, rather than of a concrete theme in Plato's philosophy. ${ }^{16}$

This option transcends the world of opinion and breaks with epic and drama. ${ }^{17}$ These seem to be only shadow. In a first critique, the epic and dramatic arts were rejected as an inferior form of speech about the gods and human beings because the speaker formally imitates the character or the other person. After insight into necessary conversion and death in philosophy, these same arts appear as avoidable because the objects they present are themselves mimetic.

In the last book of the Republic, Plato speaks of poetry a second time. His appreciation of poetry is totally negative. This judgement is the consequence of his conception of the right (orthoos) republic. Mimetic poetry is banned because it lacks knowledge that could function as a pharmakon against its own fallacies.

As in the first texts on art, poetry is banned because it is mimetic. Nevertheless, mimēsis has another meaning here. In books 2 and 3 of the 
Republic, mimēsis indicated the ambiguous relation between the actor and the spoken message. This ambivalent relation affects the veracity of the message. There were also material typological criteria. Book 10 of the Republic focuses on the veracity of the work of art and its influence on the recipient.

The argument, which becomes possible through the insight into true dialectics ascending to the sunlight and descending into the shadows of the cave-a dynamic that is marked by dying or metabole and commitment in life-takes place in four waves. The work of art has only a doubtful ontological status. The painted couch is a shadow of the many couches which are themselves made according to the idea of a couch (596b: pros tēn idēan [blepoon]). The painted couch is not even the imitation of a truth, but only of a phantasm (598b: mimēsis phantasmatos). The illusionary couch stands to the many couches, which are a realization of the phusis or the eidè, as the mimètēs stands to the dēmiourgos or poiētēs, who imitates the phutourgos. Consequently, poetry is an imitation of little ontological value. In the field of the relations between the idea and the multiple realities that mark the fundamental relations of political reality (the king-philosopher), there is no place for a third order doubling the truth of the binary ontological structure in a mirror.

This first element of criticism is linked to the epistemological status of the artist. The poet, and Homer is the privileged example, pretends to have knowledge of everything. This is a travesty and mockery of the ideal of justice that says how everyone has to fulfill his or her own task by nature in harmony. The poets are nothing but imitators of illusion and shadows of virtue without knowledge of the truth (600e). They represent a disordered technē not focused on one object but on everything. Because of this, their poems have no true content formed by a typology, and their ensemble of rhythm, metre, and harmony signifies a dangerous and fascinating magic $(601 \mathrm{~b})$. The imitator does not possess knowledge or a right opinion (602a). The epic and tragedy in particular are criticized here.

Thirdly, the arts are also anthropologically situated. Mimetic art is at three levels away from the truth. Concupiscence, or the lower part of the soul, is very open to shades, conjuring, the trickery of poetry. By using the above-mentioned principle of noncontradiction, the rational part of the soul can penetrate phantoms with the true logos and nomos of the republic. The cheating of poetry, therefore, has its influence, especially on the nonrational part of the soul, the pathos, with the primacy of concupiscence. Art destroys the rational just as democracy destroys the ideal of politics.

Beginning from this last point, the ethical influence of a work of art Philosophy East \& West can be demonstrated. The most severe charge against poetry is that it 
can harm even honorable people. The ethical harmony of humanity is achieved by the logos and the nomos. When the pathos of poetic mimẽsis gets the upper hand, there arises a dangerous perversion in which the lower feelings of humanity are stimulated. Art thus affects virtue at its very core. For the dikaiosunē exists in an inner harmony where every part of the soul does its own business under the guidance of reason. Justice in the republic consists in the fulfillment of proper tasks. The poet, who pretends to be able to speak about everything, places these truths before a mirror that changes every right relation and proportion. Art therefore signifies for the republic and for the individual a perverse and diabolic rupture. Consequently, the poet has to be banned from the republic. A single exception is made for panegyrics on the gods and on virtuous persons. For this could be helpful to the government and to the life of humanity. Plato's text on poetry closes by repeating the central place of justice: "so that not the lure of honour or wealth or any office, no, nor of poetry either, should incite us to be careless of righteousness and all excellence" (608b).

The Reader as Judge? In a final moment of reflection on Plato, we will investigate what all of this means for the reader. Plato's works are presented as dramatic dialogues: an ensemble of inscriptions that can be read. The recipient brings these inscriptions to life. Only in the act of reading the dialogue can this take place. But in this act of reading, the reader takes the position of judge, a third critical instance that can judge who is right. Plato evades this triadic structure that is typical of drama. This happens in a twofold manner.

At the level of the structure of the text, the internal pattern of the organization of language finds its correlate in the use of metalepsis. ${ }^{18}$ As a literary genre, dialogue excludes every third instance. At the same time, the third is irreducibly present in the form of the reader. This means that there exist two linguistic universes in which the dialogue is situated: proper immanence and the theatron of which the scene is a part. Despite the thematic exclusion of the third, dialogue remains a form of eris. But at the moment that the public can judge, it must become a participant in the dialogue. The position of the judge is exchanged for the position of a participant in the dialogue. This happens through the use of the trope of metalepsis. With metalepsis one steps from one linguistic universe into another. The relation between the reader and Plato is substituted for the relation between Plato and Socrates and ultimately for the relation between Socrates and the participants in the dialogue.

The prologue as mise en scène accomplishes an important function. At the beginning of the second book, Socrates says that the oration of Trasymachus is taken up again and that the first version (in book 1) was properly a prooimion (357a). The dangerous character of rhetoric is 
repeated in an objective discourse, which incorporates the position of the judge into the discourse (358b: "This, then, is what I propose to do, with your concurrence. I will renew the argument of Trasymachus"). With this difference of levels, curtains rise between the refractory reader and the text. The reader is thereby excluded as a deceptive third. One who does not want to make the step to the text is kept at a distance as someone who refuses conversion to the light of the common truth.

Together with the thematic exclusion of rhetoric, this stylistic procedure disturbs the dramatic structure of the dialogue. Inwardly, drama and rhetoric are reduced to a maieutic monologue in which the same is born; outwardly, the Platonic text becomes a sacrosanct unit in which the reader is excluded by the written character of the text and the rise of objectivizing curtains.

This problematic is intimately related to an evaluation of the written word. The fascinating and well-known analysis by Derrida states that since Plato there exists a fear of the written word. ${ }^{19}$ The written word is marked by a triple absence. The author, the recipient, and the referential world are absent. This results in repression and logophobia. Once the text exists as text, it is dead. The text has become a stone monument. ${ }^{20}$ This alienation is banned in the philosophy that wants to be present at original signification. Thus is the materiality of the text repressed, and thus does logophobia arise. The materiality of script means a threat for the ideal community of communication since that materiality grounds the position of the judge. Perhaps there exists an even more radical threat in the written word. As written down, the text is prey to the judgement of every possible other reader who is not the intended recipient. The materiality of the text implies that the text can be read in other places and at other times. Every text is exposed to a third party as judge and advocate. The presence of this reader means a continuous threat to the purity of the text that wants not to be material but only an expression of the highest ideas. The possibility of parody, as a mirror in the third-rank, contains the greatest threat to language and to the ethics that wants to be safe from every direct confrontation with the other.

Language, Ethics, and the Other in Plato. Just as the dèmiourgos structures the cosmos, the enlightened philosopher gives form to the political and ethical order out of his knowledge of the idea of the Good. ${ }^{21}$ This ontotypological structure, in which concrete life is an acceptable form of (immediate) mimēsis of the ideal life, ${ }^{22}$ presupposes several decisions concerning language. Language is brought to a certain crisis where fundamental decisions are taken. The choice is twofold and reciprocal: the primacy of the first grammatical person and the exclusion of every third party. 
other, who, in rhetoric, appears as a possible dangerous rival. But the reality of tragedy is also banned. In the tragic relation, one identifies oneself with the other (mimēsis 1 ) and looks at a third-rate reality. In this speculative movement, the diabolic rupture of contact with the other is banned. Besides, a history is created in which change and becoming are experienced as threatening. The contamination of desire (epithumia) and honor (timē) disturbs ideal harmony. Nevertheless, these two modes ground intersubjectivity. But according to Plato they are a perversion that affects the republic at its root and causes it to degenerate into the rejectable democracy ruled by the tales. This crisis of language has manifest consequences for the evaluation of the intersubjective and ethical relations that always take place in time. The choice for ideal existence implies an aversion to alterity and time. The enlightened guardian can structure the republic only according to the principles of justice, enlightened by the idea of the Good.

Many people contend that Plato's philosophy is a philosophy in crisis. In that crisis a sentence is passed. When a common standpoint mediating the different positions becomes possible-this is an aim of rhetoric - the crisis is solved. But perhaps there is more at stake in Plato. The problem may be a différend, ${ }^{23}$ an unsurmountable crisis in which Plato tries to purify language from contaminations that could alienate it from its own sources. Crisis therefore means a metanoia, a turning away from language that hides the phusis in favor of the conventional nomos.

Rosenzweig and the Multidimensionality of Language

The Inversion of Plato's Ontological Relation. After the deep cataclysm of the First World War, the dialogical thinker F. Rosenzweig broke radically with the Platonic conception of reality. ${ }^{24}$ The attitude of Plato toward drama (and, mutatis mutandis, rhetoric) was determined by his conception of truth. Temporal reality is a shadow of ideal reality, which, in turn, is made possible by the transcendent ideal of the Good. Rosenzweig inverts the image of Plato. The atemporal and autonomous figures of human being, God, and the world, as they exist in their archaeological depth, are a shadow of relational and temporal reality: "In other words, forms [Schatten] that do not occupy the same space with what we call our reality, our truth, our life, and yet hover over everything that goes on within that space. ${ }^{\prime 25}$ Where Plato wanted to direct the prisoners' gaze to the fire that articulates essence and unity, Rosenzweig thinks that one can peal visible realities like onions without finding anything on a deeper level.

According to Rosenzweig reality exists in the multiple relations between God, humanity, and the world. Truth is always a future event that does not coincide with the actual time of reality. The fundamental 
future supplies a claim of truth. Before it is possible to think the relational experience of reality, it is necessary to think the junctions of this texture as autonomous points. They form the shadows or the basement of the building of reality. These mirror realities are no illusionary deduction of eternal reality but form the hidden matrices of existence, or the dark womb from which relational life can arise. Inspired by the Spätphilosophie of Schelling, Rosenzweig discovers these irreducible grounds in mythical speech. In myths, temporal and relational reality is solidified into an eternal and unchanging figure. Reality appears in petrified time and mute language. Myth abstracts from the actuality of reality. Reality is shown in its most rudimentary structure on this side of concrete existence. Myth expresses substances in the thin intervals of atomic universes (cf. Democritus). It tears apart language and petrifies fluent grammatical connections. This datum is not an insurpassable primitive stage but the unavoidable presence of mythical darkness projecting itself again and again in reality and therefore in a certain sense constituting it. Myth precedes lived reality.

Out of these ontological presumptions it is possible for Rosenzweig to understand certain aspects of art as the presupposed experience of the autonomous ground of reality. This autonomy implies that represented reality is irreducible to something else.

The Ontological Meaning of the Mythical Forms of Art. As shadowrealties, the mythical grounds are represented in the forms of art (myth, tragedy, and the plastic arts). ${ }^{26}$ Art is autonomous and ontotypologically independant. It is the representation of mere reality in its opacity and materiality. Art shows reality as it is, on its own. This metaphorical or centripetal character of art, in which reality is represented in an image, is contrary to the metonymical structure, in which the represented image is a displacement or camouflage of idea, reality. ${ }^{27}$ As a symbolic and unconscious order, the metaphorical signifiers create the differences that make significations of God, human beings, and world possible. Thus they ground a pluralistic universe that is radically opposed to the Platonic worldview.

Although art is autonomous, it stands in a mirroring relation to reality (Star, p. 38). That autonomy implies that art, as a condensed shadow of reality, presents the dark ground of that reality as well as the Olympic lightness of being. The mimetic relation of art must not be understood in a Platonic way. As a mirror, the reign of beauty is the visual condensation or representation that gives depth to reality. This archaeological structure is as original as reality itself. The shadow reality of art is the foundation of reality. Art is a world of mute understanding, a world without real coherence or relation. Yet the different contents of art can Philosophy East \& West be brought to life. Before every real language, art as the language of the 
ineffable originates the first and mute understanding of the archaeological depths of spoken existence.

Myth, Tragedy, and the Plastic Arts as Autonomous Perceptions of Reality. Myth, the plastic arts, and tragedy are, according to Rosenzweig, expressions of the experience of the autonomy of God, the world, and humanity. Art is governed by three laws. The first law, with regard to the external form, expresses the divine character of art (Star, p. 38). It demands that the work of art be closed from everything that is not itself. The reign of beauty is an autonomous reign. The work of art is closed from the world by a crystalline wall: visible to the world but separated from it.

Besides the formal demand of beauty, art is also governed by the plastic law of inner coherence (Star, pp. 60-61). The parts of the work of art exhibit a necessary coherence between the whole and the parts of the whole. This coherence is immediately given and not brought about by an entity situated outside the work of art, for example the reality that is mirrored or imitated. This inner coherence forms the structure of the work of art. It is the ground of the beautiful figure of art. Coherence represents an autonomous sphere of meaning. This sphere is in the first place meaningful, proceeding from its own structure and not as a representation of something else. Meaning is an independent game of significance parallel to the reality of the world. Art properly represents the original and irreducible character of reality.

Thirdly, there is the question of the content of art (Star, pp. 80-81). This content is staged preeminently by Greek tragedy. Tragedy is the language of the ineffable mystery of the solitude of finite man. The silent and mute presence in the archaeological depth of existence forms the real content of art. On the stage, the existential condition of humanity, oscillating between fate and freedom, is made comprehensible but unspeakable. Such a representation of the human condition is the presupposition of real language. The visualization of mute art is the plastic dimension that precedes the existence of language. In silence, the tragic hero burns all bridges with God and the world and retreats into his or her own silence. ${ }^{28}$ Greek tragedy is marked by the paradoxical thematization of silence.

It is not surprising that death is the truth of the tragic hero. In death, the hero is shown in his or her ultimate solitude and irreducibility. The idea of immortality is the consequence of this tragic option: heroes do not die. The ancient doctrine of metempsychosis is the answer here.

The Epic, the Lyric, and Drama as Forms of Relationality. Rosenzweig presents his work explicitly as a drama. In Star I, the dramatis personae are presented in metaphorical density before entering the scene (Das neue Denken, p. 147). Star II, which deals with the relations between 

reality. Seemingly in parentheses, Rosenzweig also handles his conception of the three literary genres. ${ }^{29}$ Nevertheless, this marginal text is the royal road to Rosenzweig's triadic thinking of reality. The different possibilities of language are explored starting from the structure of grammatical pronouns and the modes of time.

The epic, lyrical, and dramatic components of every work of art are generated from the combination of the three laws that govern art. The narrative-epic component grounds the content of the event. The combination of the beauty of the whole with the individual spheres of meaning results in a spatial framework for the content of the narration. The epic component is the fruit of the work of the artist or author. It opens the space for the time of narration. This implies that the artist could be present at the work of art. But as a genius, the artist can relate with great effort the autonomy of beauty with respect to possible spheres of meaning. In this act, the artist gathers heaven and earth. From his own narrative tradition, Rosenzweig interprets this act as the biblical epic of creation. By relating God and world, Genesis 1 creates the space wherein the things can appear as work. This concept of creation is contrasted with the Timaeus of Plato, where the dēmiourgos presses his tupos on reality and creates a hierarchical ontology of unity, where every being receives its value from the mimēsis of the tupos. Epic, on the contrary, realizes a relation as the result of a fundamental symbolic Differenz that precedes every meaning and even makes every meaning possible.

The dialogical-lyrical component generates the formal depth of the work of art. The lyrics consists in the oblivion of solipsism and of the multiplicity of things. This oblivion of the plastic spatial dimensions of art makes possible the aestheticization of the most personal human existence. The concentration of autonomous beauty on the individualistic time of the human being, which forms the content of art, makes it possible for an individual work of art to represent a universal value. The lyrical dimension of art moves at the limit of oblivion and the transcending of individual time. This structure of unhiddenness marks the work of art as such. It is the reality of art itself. For this reason, art has its own ontological place. The form of art 'signifies' the openness of the human being (tragic figure) to exteriority (mythic figure). The work of art is the irruption of the other into the immanence of solipsistic existence. The lyrical structure grounds the dialogical concept that arises from the confrontation between the first and second grammatical persons. The Song of Songs, which is written in the modality of intersubjectivity, is the narrative expression. The dialogue in the Song of Songs is supported by only one objective phrase, namely that love is as strong as death (8:6).

The proper dramatic component, that is, the poetic, represents the relation between God, humanity, and the world and links the material 
possibilities of the epic space with the personal time of lyric depth. This symbiosis of interiority and exteriority takes place in reception. It is the function of the recipient. The poetical force of arts arises when the work of art reaches its recipient. Art changes the world insofar as art is received. Poetry finds its origin in representing thinking. Thought is the element of poetry, as space and time are the elements of epics and lyrics. In dramatic poetry, the tonality that colors the poem and the vocabulary of the poet are gathered and brought to life in the content of the poem. The thought represented in drama is no representation or mimésis of a tupos situated outside the work of art, but an autonomous whole of meaning that manifests itself in the tonality and the materiality of the words. Rosenzweig is far from Plato's conception of music. Plato could claim that in music the melody and the rhythm had to correspond with the logos that was standarized ontotypologically. According to Rosenzweig, in poetry there arises an original way of thinking that brings tonality (as the equivalent of melody) and the word together in a representation. In this combination, dramatic and poetic art does not represent a deeper or higher idea, but brings the recipient to real life as it is lived in the personal sphere of existence. Life is represented in poetic art as a drama, a relational game with different dimensions of existence. This drama is not a third-rate representation of a timeless idea, but the expression of life situated in the multidimensional reality of time. Drama is therefore not the most detestable form of art, but that art which brings the recipient to life.

Language, Time, and Alterity. According to Rosenzweig, dramatic poetry is the highest form of art. As a play between the divine, the human, and the world, drama implies a radical rehabilitation of the alterity that Plato's Republic experienced as a threat of the symmetrical and hierarchical order. The repressed dimension of the second grammatical pronoun is lifted up to its proper dimensions. This movement implies an intersubjective interpretation of the whole of reality. Rosenzweig recognizes another topography of the linguistic field than does Plato, the eminent representative and founder of the Greek tradition.

Rosenzweig's structure of linguistic possibilities, as brought in through the literary genres, is linked with the triadic structure of pronouns and the modalities of time. A rereading of the Grammar (Star, pp. 124-131, 173-185, 227-238), augmented by Rosenzweig's critique on Buber's Ich und $\mathrm{Du},{ }^{30}$ makes it possible to describe the relation between linguistic forms, pronominal forms, and temporal modes.

As the language of creation, the epic is governed by the deictic functions by which an object is defined against others. The privileged verbal form is the third person indicative. This means that things are put side by side in an objective space. This objective and past dimension 
expresses the presence of the perceptible world. As the language of revelation, the lyric is generated from the original first person. The $I$ is appealed to in the vocative. Through shame, openness to the second person arises. The verbal modality is that of the imperative, the mode of the first and the second person in actual time. As the language of redemption, drama is grounded in the sentence "Er ist gut." This sentence is spoken in the optative, the mode of future time, and in the firstperson plural, the mode of community.

The Epic

$1 / 3^{\circ}$ person

indicative

past

creation
The Lyric

$1 / 2^{\circ}$ person

imperative

present

revelation
Drama

$1^{\circ} / 2^{\circ} / 3^{\circ}$ person

optative

future

redemption

Rosenzweig's critique of Buber's Ich und Du makes it possible to nuance this first scheme. A first aspect of Rosenzweig's criticism concerns Buber's underestimation of the Ich-Es relation. From the first pages on, Buber makes an important distinction between the two fundamental words Ich-Du and Ich-Es. This distinction converges with the distinction experience-relation. The world of relations contains the community with nature (das Leben mit der Natur), with humanity (das Leben mit den Menschen), and with ideal values (das Leben mit den geistigen Wesenheiten). These relations are exclusive and assume the whole of reality. Relations with the objective world are reduced by labeling them as objective and past (Gegenstand). True reality is a matter of presence (Gegenwart). This implies a monopolization of presence and an underestimation of the Ich-Es relation. ${ }^{31}$ Rosenzweig places the spoken Es against the thought Es. The Es is marked by its own autonomy, in contrast with the $D u$ in Buber's Ich-Du relation. It represents the objectivity of the narrated past. The third person expresses this past independence of reality. This dimension is linked with the Ich-Du relation and must not be disconnected. The three grammatical pronouns are interrelated and not isolated entities. The isolation of dialogical lyrics from epics, according to Rosenzweig, makes every dramatic interaction impossible.

In the second point of his critique, Rosenzweig investigates the temporality of fundamental words. In contrast to Buber, Rosenzweig distinguishes an Er-Es, an Ich-Du, and a Wir-Es relation-respectively, creation, revelation, and redemption. Against Buber, Rosenzweig denies the primacy of the Gegenwart and thinks the relations temporally. The conclusion is that the multiple manifestation of the other, in the pronouns, implies a multiplicity of times that is possible only through the multiplicity of language. 
Ethical Dynamics and the Forms of Art. The rehabilitation of the three literary genres makes it possible to set up a triadic way of thinking that transcends the binary oppositions predominant in Western philosophy since Plato.

Rosenzweig develops a vision of the dynamics of the ethical subject that leaves behind the autarkeia of the Greek-Western culture. According to Plato, justice exists in the realization of proper tasks within the ordered republic. This order is marked by a strong parallelism between the parts of the soul, with their virtues, and the classes of society. Conversely, Rosenzweig comprehends the ethical dynamic in a triadic way. As a solipsistic and autonomous figure, the human being is characterized by an unconditioned but finite freedom and a potential for human possibilities. Freedom is originally directed toward the realization of the intrinsic humanity. As a perception of the first pronoun, the I, freedom meets its limits and is confronted with what transcends it, the word and the law, which interrogates freedom in a personal confrontation of its legitimacy. In this feeling of metaphysical shame, freedom is reoriented. The personal transcendence of alterity confronts the self-satisfied freedom with its finitude and impotence but reaches at the same time a new space and time. Freedom is freed from its solipsism in assuming an ethical task. After this experience of conversion, the other person appeals as a representative of an objective but finite world (the third person) awaiting completion. The irreducible appearance of the other person introduces a structural alterity into existence. Attention to this alterity is possible because freedom is converted from itself. The answer of freedom exists in the realization of an intrinsic humanity in favor of the unaccomplished world. The objective world is the structural field of action wherein freedom can be exteriorized in the humanization of the world. Ethical redemption consists in the fact that the I meets the objectivity of the world as a second person. This ethical relation is not the immediate realization of freedom in the world or a subject-object relation, but is made possible by metaphysical alterity. The distinction between the origin (freedom), the presuppositions (alterity), and the concrete field of action (world) is, in Rosenzweig's thought, reflected as the relation between the three grammatical pronouns. The binary relation between freedom and world is left behind to interpret the ethical relation from a transethical point of view that makes ethical actuality in the present possible but also transcends it.

This multidimensional thinking of the ethical relation with the other as transcendence and the other as an appeal for commitment is, in the text of Rosenzweig, made possible by taking seriously the ambiguities of language and by avoiding a repression of its rich possibilities. The different literary genres form a framework in which it is possible to interrelate the rich meanings of the divine, the human, and the world. These 
archaeological signifiers were instaured in the mythical forms of art. Epic space and lyric depth open a sphere of meaning in which humanity can be confronted with a reality that appears in the second person. The valuation of this third dimension implies the end of the binary symmetries that mark Western ethical thinking. In his study on Hegel $^{32}$ and in some remarks on the Star, Rosenzweig shows how the irreducibility of the human person who exists outside world history implies a permanent critique of the flow of history. It is not that history judges, but that the alterity of the second person makes the anonymous objectivity of history impossible. Inspired by this, C. Chalier speaks of a promised history that is a radical critique of the bloody revolutions and evolutions in world history. ${ }^{33}$

Thinking out of Conversion. As in Plato, Rosenzweig's thinking is the fruit of a conversion. Under the influence of Meinecke and Rickert, the young Rosenzweig considered the world a sequence of relative stages. A fixed point of truth that can orient reality was not possible. The year 1913 was very important for Rosenzweig's biography. It is seen as the year of his conversion. His conversations with Rosenstock-Huessy, who converted from Judaism to Christianity, and his perception of Jewish liturgy should have pointed Rosenzweig toward the absoluteness of the loving God. This conversion was strengthened by the experience of the First World War. Through this experience he no longer saw the world from the standpoint of a spectator surveying its passing episodes but as a scene in which God, humanity, and the world are the actors. This conversion signified a step from the position of spectator to that of actor. In this sense, it can be compared with the incorporation of the spectator in Plato's text. But the conversion is not merely a hagiographical or anecdotal datum. As in Plato, it is the heartbeat of thinking. Where the Platonic tradition finds in death or in crisis the way out of the illusions of the temporal world (philosophy as ars moriendi), the shock of death means for Rosenzweig the conversion from the binary discourse of Western philosophy that dies to concrete reality in order to find a higher level of reality. The first pages of the Star can be read as a critique of Socrates' swan song in the Phaedo and as an aversion to the stoic ideal of aphobia and amor fati. The frightening reality of death is the cry of Nietzsche to remain faithful to the earth. The trauma of death places man before the horrible abyss of nothingness. Existential doubt about the existence of God, the reality of the world, and the freedom of humanity undermines the pillars of Western-idealistic thought. Humanity cannot escape this anxiety by moving in a parallel discourse that would transcend the corruption of time by postulating an ideal and eternal reality. But in this anxiety, humanity is converted from the otherwordly speculations that tear it away from the concrete world. As Plato interpreted the conversion 
in the cave as therapy, ${ }^{34}$ so does Rosenzweig interpret the conversion from idealistic philosophy as the healing of sick thinking. ${ }^{35}$ Rosenzweig pleas for a therapy from Platonic conversion.

The Reader and the Metaphor of the Trial. It is remarkable that in Rosenzweig's discourse the metaphor of the trial received new attention. Kant and Hegel show that this metaphor never left Western philosophy. But the judge remained immanent. According to Rosenzweig, human freedom has to be justified before a transcendent judge. After the crisis in personal confrontation with the law, freedom is turned into an ethicalredemptive dynamic focused on the world. This process of conversion, which is made possible through the presence of the judge, culminates in the dramatic interactions of the human being in the world. The liturgy, as religious drama, expresses this future-oriented and dynamic interaction. After the confrontation with the law as a second person, the first person is opened to a common we. As hymn, it forms the culminating point of the community. The first-person plural includes everyone but also finds an irrecuperable limit. Because the community is the answer to a transcendent call directed at freedom, it is always situated. But openness for the future implies that the community cannot be the end point or a closed totality. In its dynamic of being an answer, the community refers to an external instance that can criticize. The ethical dynamic of redemption stands under the judgment of absolute transcendence.

This twofold rehabilitation of the juridic metaphor is linked to the way in which Rosenzweig presents his text to the reader. In contrast to Plato, Rosenzweig presents a narrative (epic) philosophy. The Star unfolds, in an architectonic way, God, humanity, and the world, and subsequently creation, revelation, and redemption, and finally Judaism, Christianity, and truth. This systematic concept is nevertheless broken open by an existential way of thinking. Anxiety before death, the twilight of the gods, and the relativization of the world cross the system of Star l; the dialogical relations and the topics of guilt, reconciliation, and ethical appeal limit the structure of Star II. Systematic discourse is continuously disturbed by an existential way of speaking. Nevertheless, this way of speaking remains within the limits of the epic genre. But in the final sentence, the reader is directly addressed. After the objective, analytical, and synthetic lecture of the speculative story, the reader is invited to contemplate the whole as a second person and to enter into a dialogue. Just as the lyrical relation in the Song of Songs was grounded in only one objective sentence, epic philosophy is by only one sentence transformed into a dialogical and dramatic linguistic game that at the same time fascinates and keeps the reader at distance: "Whither, then, do the wings of the gate open? Thou knowest it not? Into life" (Star, p. 424). After ending the Star, Rosenzweig wrote numerous letters, short commentaries, and 
many translations. His conversion to the dramatic structure of life made it impossible to think only in an objective way. This has to do with the interpretation of script. According to Plato, writing was a deduction of the spoken word. Logophobia arose out of this. But, according to Rosenzweig, the written word, especially Hebrew as a holy language, has a material alterity that questions the spoken word. Written language precedes human freedom and criticizes it. Thus, scripture is not a degeneration or corruption of the presence that characterizes speech and Western thinking, but its alterity is, as judge, the critique of acting and thinking.

\section{Conclusion}

Ethical discourse is not autonomous, but is made possible by the linguistic field in which it is expressed. Language is not only an instrument of communication but the possibility of thinking. Plato's text illustrates that language has to be brought to a crisis before ethical reflection can be developed. Rosenzweig shows the ambiguity of this judgement. When certain linguistic possibilities are excluded, certain dimensions of reality cannot be articulated. Censure is both formative (Plato) and dangerous (Rosenzweig).

\section{NOTES}

1 - This text is based on a lecture, "Taal, ethiek en de andere: Een comparatieve studie van Plato and Rosenzweig," given on the occasion of The First International Conference on the Possibilities and Application of Comparative Philosophy, Antwerp (Belguim), 16-18 September 1994. Some of its ideas are the result of an intense dialogue with Drs. P. Thoen and Drs. G. van Coillie, whom I cordially thank.

2 - E. Auerbach, Mimesis: Dargestellte Wirklichkeit in der abendländischen Literatur (Bern, 1946); J. Wertheimer, "Der Guter Gefährlichste, die Sprache," in Zur Krise des Dialogs zwischen Aufklärung und Romantik (München, 1990).

3 - S. Rimmon-Kenan, Narrative Fiction: Contemporary Poetics (London/New York, 1984); R. Jakobson, "Linguistics and Poetics," in T. A. Serbeok, ed., Style in Language (Cambridge, Massachusetts, 1960, pp. 350-358), and U. Eco, Lector in fabula: Le rôle du lecteur ou la Coopération interprétative dans les textes narratifs, Biblio Essais, 4098 (Paris, 1993).

Philosophy East \& West

4 - The deconstructionist strategy of reading is inspired by Nietzsche's texts on rhetoric: Friedrich Nietzsche on Rhetoric and Language, 
ed. and trans. by S. Gilman, C. Blair, and D. J. Parent (New York/ Oxford, 1989); F. Nietzsche, "On Rhetoric: Description of Ancient Rhetoric: Lecture, Summer, 1874, 3 Hours," in C. Blair, "Nietzsche's Lecture on Rhetoric," Philosophy and Rhetoric 16, (1983): 94-129. See also S. ljsseling, Rhetoric and Philosophy in Conflict: An Historical Survey (The Hague, 1976); the various contributions to S. Ijsseling and G. Vervaecke, eds., Renaissances of Rhetoric, (Symbolae, Facultatis Litterarum Lovaniensis, Series D: Litteraria, vol. 7, (Louvain, 1994); and A. Tebartz-Van Elst, Ästhetik der Metapher: Zum Streit zwischen Philosophie und Rhetorik bei Friedrich Nietzsche (Freiburg/München, 1994).

5 - Wertheimer, Der Guter Gefährlichste, p. 16.

6 - E. Levinas, who, after the holocaust, takes over Rosenzweig's thinking in a sublime manner, is ambivalent regarding the Socratic maieutic. The least one can say is that the Levinasian interpretation of being taught by the idea of the Infinite is far more than Socrates' pedagogy of recollection. Cf. E. Levinas, Totalité et Infini: Essai sur l'extériorité (The Hague, 1968), pp. 52, 211, 236, 256.

7 - Citing Plato in Twelve Volumes, with an English translation by $\mathrm{O}$. Shorey, Loeb Classical Library, (London/Cambridge, Massachusetts, 1969). See also J. Annas, An Introduction to Plato's Republic (Oxford, 1981).

8 - Diogenes Laertius, De vitis, dogmatibus et apophthegmatibus clarorum philosophorum, III, 37.

9 - Gorgias, Encomion Helenae, par. 8. Cf. S. Ijsseling, Rhetoric, 13-25 and idem., Apollo, Dionysios, Aphrodite en de anderen Griekse goden in de hedendaagse filosofie (Baarn, 1994, 84-126).

10 - Cf. K. Dorter, "Socrates' Refutation of Trasymachus and Treatment of Virtue," Philosophy and Rhetoric 7 (1974): pp. 26-27.

11 - Cf. C. Verhoeven, "Sofisten: Natuur en conventie," in Verhoeven, Een velijnen blad: Essays over aandacht en achterdocht (Baarn, 1989, 163-173).

12 - In Gorgias 510e-502b, Plato indicates an explicit parallel between rhetoric and the other literary arts.

13 - This "onto-typo-logical" interpretation of the arts is based on D. De Schutter's lecture, "Lacoue-Labarthe over politiek als fictie," given at the Werkgroep franse politieke filosofie, at the K. U. Leuven Campus Kortrijk, on 25 May 1994.

14 - Cf. Euripides, The Bacchanals, in Works, vol. 3, ed. A. S. Way, Loeb Classical Library, (London, 1962), vv. 775-861.

L. Anckaert 
15 - C. Verhoeven, Het medium van de waarheid: Beschouwingen over Plato's houding tegenover de poëzie (Baarn, 1988, 132-136).

16 - Cf. K. Bormann, Platon (Freiburg/München, 1993, 37-44).

17 - This is the thesis of Verhoeven, ibid.

18 - Diogenes Laertius, De vitis III, 5-6, argues that Plato's meeting with Socrates meant a rupture with his past as tragedian.

19 - Cf. J.-F. Lyotard, Le différend (Paris, 1983).

20 - J. Derrida, "La pharmacie de Platon" and "La double séance," in La dissémination, Collection Points, Essays 265, (Paris, 1993, 77213, 214-347).

21 - Cf. D. Thiel, Platons Hypomnemata: Die Genese des Platonismus aus dem Gedächtnis der Schrift (Freiburg/München, 1993).

22 - Cf. L. Schäfer, "Herrschaft der Vernunft und Naturordnung in Platons Timaios," in L. Schäfer and E. Ströker, eds., Naturauffassungen in Philosophie, Wissenschaft, Technik, band 1, Antike und Mittelalter (Freiburg/München, 1993), 49-83.

23 - J. Derrida distinguishes different shifts in the concept of mimēsis ("La double séance," n. 8). The 'good' form reproduces the pregiven idea, the 'bad' form-in our reading, the third-rank mimēsisappears as a mad play.

24 - J.-F. Lyotard, Le différend.

25 - F. Rosenzweig, "Der Stern der Erlösung," in Der Mensch und sein Werk: Gesammelte Schriften, band 2, ed. R. Mayer (The Hague, 1976) (translation: The Star of Redemption, trans. R. Hallo [London, 1970]); L. Anckaert and B. Casper, Franz Rosenzweig: A Primary and Secondary Bibliography, Instrumenta Theologica 7 (Louvain, 1990).

26 - "Das neue Denken", in Gesammelte Schriften, band 3, ed. R. and A. Mayer, p. 146 (translation taken from N. N. Glatzer, Franz Rosenzweig: His Life and Thought [New York, 1953], p. 194).

27 - Cf. Z. Levy, "Über Franz Rosenzweigs Auffassung des Mythos," in W. Schmied-Kowarzik, ed., Der Philosoph Franz Rosenzweig (Freiburg/München, 1988), 987-996.

28 - Cf. L. Anckaert, "Franz Rosenzweigs Stern der Erlösung: Een hermeneutische en retorische benadering," in R. Munk and F. J. Hoogewoud, eds., Joodse filosofie tussen rede en traditie: Festschrift $H$. J. Heering (Kampen, 1993), 223-241.

Philosophy East \& West

29 - Cf. J. P. Vernant, "Tensions et ambiguïtés dans la tragédie grecque," in J. P. Vernant and P. Vidal-Naquet, Mythe et tragédie en 
Grèce ancienne, tome 1 (Paris, 1986), p. 25: "La tragédie prend naissance quand on commence à regarder le mythe avec l'oeil du citoyen. Mais ce n'est pas seulement l'univers du mythe qui sous ce regard perd sa consistance et se dissoud. Le monde de la cité se trouve du même coup mis en question et, à travers le débat, contesté dans ses valeurs fondamentales."

30 - Star, pp. 145-150; 188-198; 242-248. Star. p. 191: "Art remains piecework.... And thus art is an essential episode, albeit only an episode, for us in all the books of this Part." Besides this statement Rosenzweig claims that "among everything Spoken, it is that which not should remain unspoken." Art not only must be interpreted as objective datum, but becomes a revelation when it is taken up in language. Rosenzweig concludes his treatise on the arts by stressing the importance of aesthetics: "There [at the end of Star II] it will also become clear that this whole doctrine of arts is, in the final analysis, more after all than a mere episode as which, admittedly, it figures here" (Star, p. 198). Rosenzweig explicitly links his aesthetics of the literary genres with his considerations on art, in Star I. Star, p. 191: "In the previous book we began to describe its basic concepts; now we continue this description on the basis of revelation, the 'category' which has been added in this book."

31 - M. Buber, "Ich und Du," in Buber, Das dialogische Prinzip (Heidelberg, 1954; 1984), 5-136. Rosenzweig wrote his critique in a letter to Buber: "Briefe und Tagebücher," Gesammelte Schriften, band 1, pp. 824-827. The most important article on this topic is B. Casper, 'Franz Rosenzweig's Criticism of Buber's 'I and Thou', in $\mathrm{H}$. Gordon and J. Bloch, eds., Martin Buber: A Centenary Volume (New York, 1984), 139-159.

32 - "Briefe und Tagebücher," p. 824 [undated letter to Buber]: "Sie geben dem Ich-Du im Ich-Es einen Krüppel zum Gegner. Daß dieser Krüppel die moderne Welt regiert, ändert nichts daran, daß es ein Krüppel ist. Dieses Es haben Sie freilich leicht abführen."

33 - Hegel und der Staat (München/Berlin, 1920).

34 - C. Chalier, L'histoire promise (Paris, 1992).

35 - Cf. C. Verhoeven, "De bekering van Socrates," in Verhoeven, De letter als beeld (Baarn, 1987), 91-106. 